\title{
Self-inflicted skin lesions: the importance of a proper diagnostic and therapeutic approach
}

\author{
Dermatoza wywołana - znaczenie prawidłowego podejścia diagnostycznego \\ i leczniczego
}

Dimitre Dimitrov', Radomir Reszke², Jacek Szepietowski²

'PMW/SKMC Dermatology, Abu Dhabi, United Arab Emirates

2Department of Dermatology, Venereology and Allergology, Wroclaw Medical University, Wroclaw, Poland

Przegl Dermatol 2016, 103, 475-478

DOI: 10.5 | |4/dr.2016.63837

\section{KEY WORDS:}

psychodermatology, selfinflicted skin lesions, factitious dermatosis.

\section{SŁOWA KLUCZOWE:}

psychodermatologia, samouszkodzenia, dermatoza wywołana.
ADDRESS FOR CORRESPONDENCE: Prof. Jacek Szepietowski

$\mathrm{MD}, \mathrm{PhD}$

Department of Dermatology, Venereology and Allergology Wroclaw Medical University 1 Chalubinskiego St 50-368 Wroclaw, Poland Phone: +48 601534853 E-mail: jacek.szepietowski@ umed.wroc.pl

\begin{abstract}
Introduction. Patients with self-inflicted skin lesions (SISL) are most often referred to dermatologists. Since psychological and psychiatric conditions might be the underlying reasons for the behavior of these patients, the psychology-associated component should always be kept in mind when approaching such individuals.

Objective. To discuss distinctive aspects of the approach towards patients with SISL and emphasize the most relevant issues concerning the management of psychodermatoses.

Case report. We present a case of a 13-year-old girl with a 6-month history of skin lesions misdiagnosed as allergic contact dermatitis. Conscientious history taking and physical examination enabled the diagnosis of SISL.

Conclusions. The proper approach to patients presenting with psychodermatoses differs from that for other dermatological patients and requires considering several additional aspects. We would like to emphasize the distinguishing aspects and importance of the proper approach to patients with SISL that might aid clinicians in diagnosing and treating these individuals in the future.
\end{abstract}

\section{STRESZCZENIE}

Wprowadzenie. Pacjenci z dermatozą wywołaną są zwykle kierowani do dermatologów. Schorzenia o podłożu psychologicznym i psychiatrycznym mogą wpływać na zachowanie pacjentów, dlatego należy zawsze rozważyć czynniki związane z psychiką w postępowaniu z takimi osobami.

Cel pracy. Omówienie szczególnych aspektów podejścia do pacjenta z objawami samouszkodzeń i podkreślenie najważniejszych odmienności w postępowaniu z pacjentami z psychodermatozami.

Opis przypadku. Opisujemy przypadek 13-letniej dziewczynki, u której od 6 miesięcy rozwijały się zmiany skórne błędnie diagnozowane jako alergiczne kontaktowe zapalenie skóry. Dokładne zebranie wywiadu od rodziców wraz z badaniem fizykalnym umożliwiło ustalenie rozpoznania dermatozy wywołanej.

Wnioski. Prawidłowe podejście do pacjentów z psychodermatozami różni się od podejścia do pacjentów z pozostałymi schorzeniami skór- 
nymi i wymaga rozważenia kilku dodatkowych zagadnień. Opisany przypadek ma podkreślić cechy wyróżniające pacjentów z psychodermatozami oraz znaczenie prawidłowego postępowania w ich przypadku i w ten sposób pomóc klinicystom w diagnozowaniu i leczeniu tych pacjentów w przyszłości.

\section{INTRODUCTION}

Patients with self-inflicted skin lesions (SISL) are most often seen by dermatologists. It is thought that SISL accounts for between 1 in 200 and 1 in 2,000 dermatological consultations [1]. Some of these patients might be brought by family members, relatives, friends or caregivers.

The diagnosis is often straightforward, but certain patients - those who intentionally conceal the origins of the lesions - might remain under-recognized and under-diagnosed for a long period of time [2]. Moreover, such individuals are frequently referred for numerous unnecessary investigations and consultations with other specialists and finally given numerous treatments needlessly, the latter being associated with various adverse effects. Taking a proper history from the patients, parents or caregivers might be crucial during the process of establishing the correct diagnosis, especially in cases with suspected SISL. It is well known that various psy-

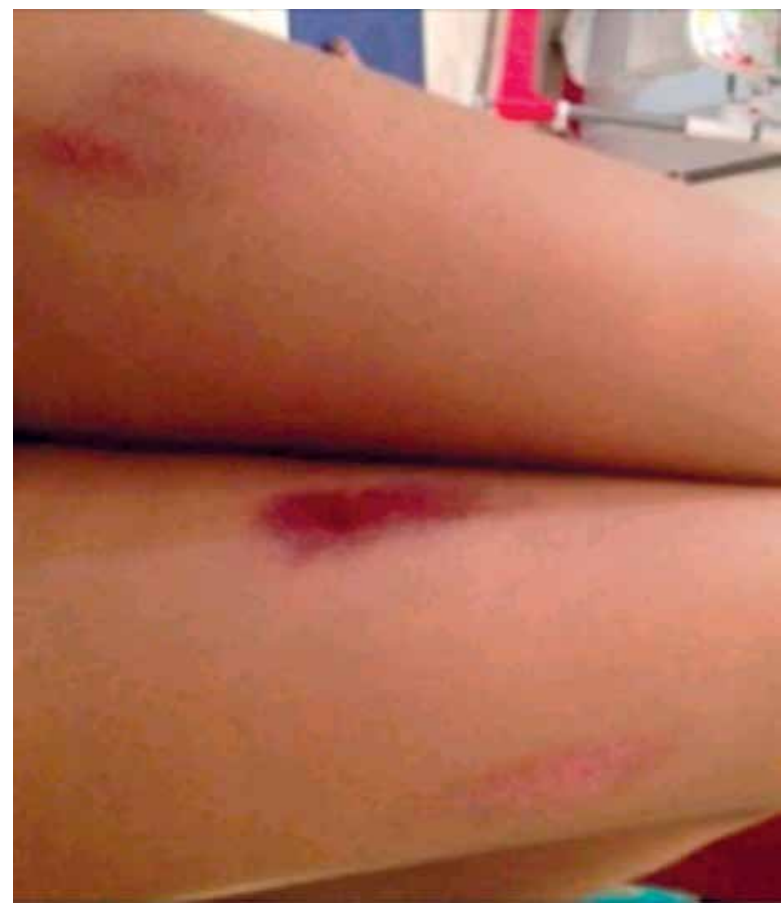

Figure I. Bilateral lesions located on the shins Rycina I. Zmiany zlokalizowane obustronnie na podudziach chological and psychiatric conditions may be the underlying reasons for the behavior of these patients. Therefore, the psychological component should always be kept in mind. These patients differ from the rest of dermatological patients. Patients with "typi-

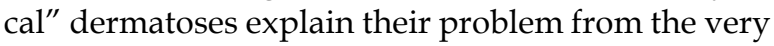
beginning, and describe the progress of the disease until the moment of the consultation. In contrast, patients with SISL are characterized by a so-called "hollow history". The dermatological condition supposedly appeared suddenly and exacerbation occurred without anybody witnessing it, apart from the patients themselves [3].

\section{OBJECTIVE}

We present a case of a patient with SISL and diagnostic problems that underline the importance of a proper clinical approach to such patients.

\section{CASE REPORT}

A 13-year-old girl was brought to one of us (DD) by parents who believed she had an allergy. The problem had started 6 months before the consultation, during holidays at a seaside as a result of contact with jellyfish. Despite the treatment new lesions appeared every now and then. Within the last 6 months the family had visited many dermatologists and other physicians. Numerous investigations were performed, including skin biopsy, biochemistry and brain magnetic resonance imaging (MRI), none revealing clinically relevant abnormalities. Several diagnoses, including a strong suggestion of allergic contact dermatitis, were made and numerous medications were prescribed without any therapeutic success.

Upon examination, geometric well-defined erythematous lesions with erosions located mostly on upper and lower extremities, several on the abdomen, were seen. Lesions were partially healing with various degrees of hyperpigmentation. Several hyperpigmented macules were observed mainly on the periphery of the lesions (Figures 1 and 2). Predictably, during the consultation the parents expressed 


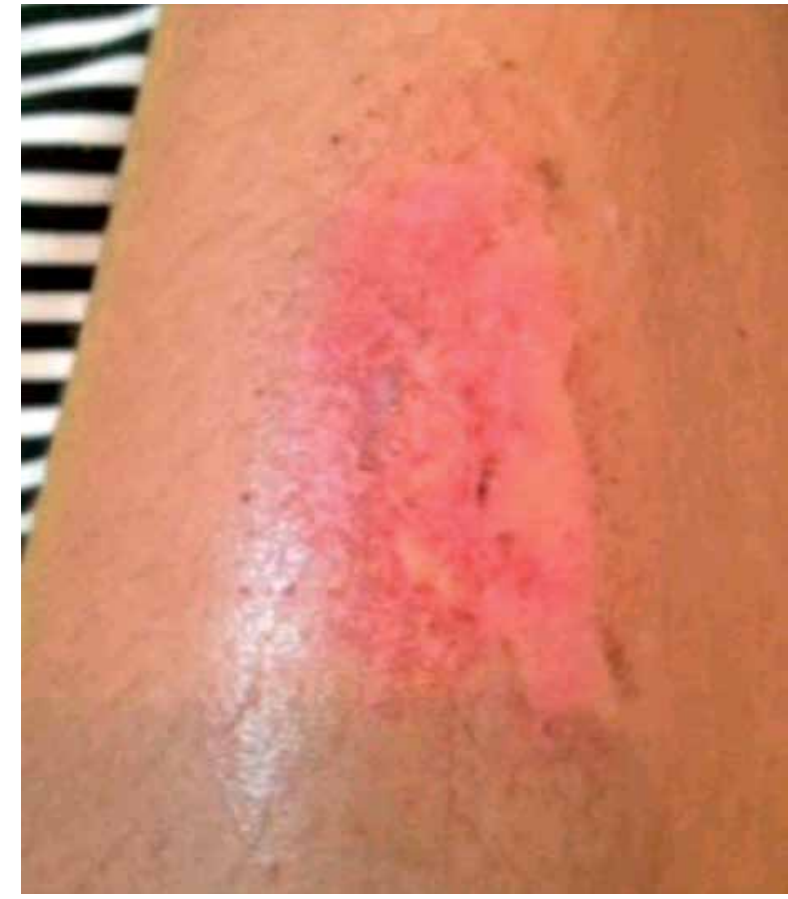

Figure 2. Well-defined erythematous lesions located on the lower leg. Erosions and hyperpigmentation on the borders are also visible Rycina 2. Dobrze odgraniczone zmiany rumieniowe zlokalizowane na podudziu. Na obrzeżach zmian widoczne nadżerki oraz hiperpigmentacja

anxiety and irritation concerning the ineffectiveness of previous therapy. However, the patient did not seem aggrieved by the situation. She explained that skin changes appeared suddenly and she could not provide any explanation of the underlying cause. A subtle smile was noted several times, which raised suspicions. Since the morphology of the lesions implied the diagnosis of SISL, the suspected diagnosis was carefully proposed. Both father and daughter firmly stated this was not the case.

A topical antibiotic was prescribed, the family was reassured and a follow-up visit was scheduled in a few weeks. When the family left, the father was called back and was provided with necessary information concerning SISL. He was also asked to observe the daughter and her behavior very carefully with his wife. After 2 days he called and stated that they had discovered the girl inducing lesions with a sponge in the bathroom (Figure 3). The patient admitted to such behavior. Consultation with a psychiatrist ensued and the diagnosis of adjustment disorder (F43.2 according to ICD-10 classification) was established. In fact, the family had moved to the United Arab Emirates from a non-Arabic, non-English speaking country a year ago. The girl had been living with many relatives and friends before. The father started working long hours and the mother delivered a new baby. Both parents hardly had time to spend with the older daughter. She attended an

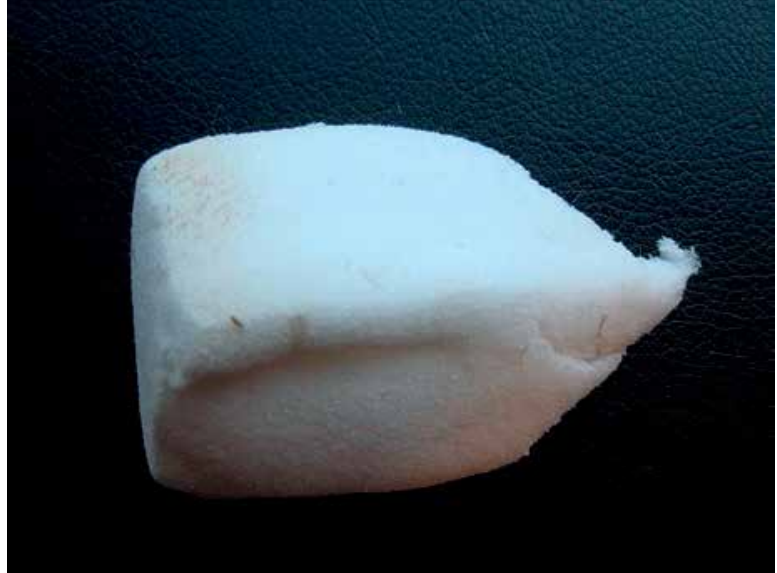

Figure 3. Bathroom sponge was used by the patient to elicit cutaneous lesions

Rycina 3. Gq̨bka do kąpieli posłużyła pacjentce do mywołania zmian skórnych

English-speaking school where nobody spoke her native language. She decided to induce cutaneous lesions to focus her parents' attention on her. In order to address the issue, the entire family attended psychological consultations and instigated the recommended lifestyle changes. The skin lesions healed spontaneously, and at 3-year follow-up the girl was still free from "skin allergy".

\section{DISCUSSION}

Self-inflicted skin lesions have a rather controversial and confusing nomenclature. Various relevant terms can be found in the medical literature. A position paper from the European Society for Dermatology and Psychiatry (ESDaP) proposed in 2014 a new classification and terminology for SISL [4]. The precise epidemiology is difficult to establish for a range of reasons: the diagnostic challenge, the terminological controversies, the behavior of the patients characterized by concealing the facts and misguiding the physicians, etc. The prevalence of factitious disorder in dermatology (previously called dermatitis artefacta) in the pediatric population was reported to be 1 case in 23,000 persons [5]. The highest incidence occurs between late adolescence (11-14 years) and early adulthood. Most patients are females [6].

Patients feel emotionally uninvolved during the consultation, which was observed in our case as well. A proper approach to such patients is crucial to establish the diagnosis. Since these patients differ from the rest of dermatological patients and the underlying psychological component is crucial, these factors should be kept in mind by the physician. Numerous psychological/psychiatric conditions can be found in association with SISL, but in most cases 3 groups are encountered: adjustment disorders, depressive 
disorders and personality disorders [3]. The frequency of emotional disorders in dermatological patients has been reported to range between $25.2 \%$ and $33.4 \%$ [7-9]. The prevalence of psychosomatic disorders among patients with skin problems is three times higher in comparison with somatically healthy control cohorts $[8,10]$.

Undoubtedly, the approach to patients with psychodermatoses differs from approaching the rest of dermatological patients. Several aspects should be considered by the physician during history taking: Could we rely only on the data provided by the patient? Who else should we ask? How critical should we be? How should we discuss the problem with the patient? What location should we choose to have a discussion with the patient? Where should we sit during the discussion? How should we behave with these patients? One would expect that therapists who deal with such patients must be well prepared for that. Contrary to this expectation, a study found that one-third of physicians treating patients with dermatological factitious disorders believe that they are insufficiently informed in regard to the diagnostic approach [11]. The proper communication is of paramount importance particularly with these patients. Another study found that doctors with good communication skills experienced fewer difficult consultations (8\% vs. $23 \%$ ) [12].

Dermatologists are well trained to recognize the morphology of various skin diseases, interpret histopathological findings, and apply topical and systemic treatment. However, we believe that more attention should be paid during dermatological residency to psychodermatology, thereby aiding future dermatologists to diagnose and treat various psychology-associated problems, including SISL, properly.

\section{Conflict of interest}

The authors declare no conflict of interest.

Received: 1 VII 2016

Accepted: 30 IX 2016

\section{References}

1. Zalewska A., Kondras K., Narbutt J., Sysa-Jędrzejewska A.: Dermatitis artefacta in a patient with paranoid syndrome. Acta Dermatovenerol Alp Panonica Adriat 2007, 16, 37-39.

2. Barańska-RybakW.,CubalaW.J.,KozickaD.,SokołowskaWojdylo M., Nowicki R., Roszkiewicz J.: Dermatitis artefacta - a long way from the first clinical symptoms to diagnosis. Psychiatr Danub 2011, 23, 73-75.

3. Millard J., Millard L.: Factitious skin disorder (dermatitis artefacta). [in:] Practical psychodermatology. A. Bewley, R. Taylor, J. Reichenberg, M. Magid (eds.), Wiley Blackwell, Oxford, 2014, 142-149.

4. Gieler U., Consoli S.G., Tomás-Aragones L., Linder D.M., Jemec G.B., Poot F. i inni: Self-inflicted lesions in dermatology: terminology and classification - a position paper from the European Society for Dermatology and Psychiatry (ESDaP). Acta Derm Venereol 2013, 93, 4-12.

5. Koo J.Y.M., Ting P.T., Elston D.M., Butler D.F., Chan D.F., Szepietowski J.C.: Dermatitis artefacta. Medscape. Updated: Jan 06, 2016. Available at: http:/ / emedicine.medscape. com/article/1121933-overview\#a5

6. Ehsani A.H., Toosi S., Shahshahani M.M., Arbabi M., Noormohammadpour P.: Psycho-cutaneous disorders: an epidemiologic study. JEADV 2009, 23, 945-947.

7. Picardi A., Abeni D., Melchi C.F., Puddu P., Pasquini P.: Psychiatric morbidity in dermatological outpatients: an issue to be recognized. Br J Dermatol 2000, 143, 983-991.

8. Hughes J., Barraclough B., Hamblin L., White J.: Psychiatric symptoms in dermatology patients. Br J Psychiatry 1983, 143, 51-54.

9. Aktan S., Ozmen E., Sanli B.: Psychiatric disorders in patients attending a dermatology outpatient clinic. Dermatology 1998, 197, 230-234.

10. Windemuth D., Stücker M., Hoffmann K., Altmeyer P.: Prävalenz psychischer Auffälligkeiten bei dermatologischen Patienten in einer Akutklinik. Hautarzt 1999, 50, 338-343.

11. Fliege H., Grimm A., Eckhardt-Henn A., Gieler U., Martin K., Klapp B.F.: Frequency of ICD-10 factitious disorder: survey of senior hospital consultants and physicians in private practice. Psychosomatics 2007, 48, 60-64.

12. Poot F.: Doctor-patient relations in dermatology: obligations and rights for a mutual satisfaction. JEADV 2009, 23, 1233-1239. 